\title{
THERMODYNAMIC ANALYSIS OF SYNTHESIS GAS PRODUCTION FROM AUTOTHERMAL REFORMING OF METHANE
}

\author{
T. L. de SOUZA ${ }^{1}$, V. S. T. da SILVA ${ }^{2}$, L. CARDOZO-FILHO ${ }^{1}$ \\ ${ }^{1}$ Universidade Estadual de Maringá, Departamento de Engenharia Química \\ ${ }^{2}$ Universidade Federal do Rio de Janeiro, Programa de Engenharia Química \\ E-mail para contato: tls.engqui@gmail.com
}

\begin{abstract}
In this work a thermodynamic analysis of methane autothermal reforming (ATR) was performed to investigate syngas production using entropy maximization method. The main evaluated parameters were equilibrium compositions, including coke formation, syngas production, and equilibrium temperature.as a function of oxygen to methane mole ratio $(\mathrm{O} / \mathrm{M})$ and steam to methane ratio $(\mathrm{S} / \mathrm{M})$ at different inlet temperatures (IT) pressures (P).The nonlinear programming problem formulated was implemented in GAMS ${ }^{\circledR}$ and solved using CONOPT2 solver. Suitable conditions for the production of syngas both methanol synthesis and Fischer-Tropsch synthesis are S/M between 0 and $0.5, \mathrm{O} / \mathrm{M}$ between 0.25 and 0.5 , and all studied range of IT $\left(400-1000{ }^{\circ} \mathrm{C}\right)$ and $\mathrm{P}$ (1-50 bar). Under these conditions, coke formations can be thermodynamically inhibited.
\end{abstract}

\section{INTRODUCTION}

Synthesis gas, a mixture of $\mathrm{H}_{2}$ and $\mathrm{CO}$, is an essential intermediate to produce many primary chemicals (Souza e Schmal, 2005; Gao et al., 2008; Halabi et al., 2008). In FischerTropsch synthesys (FTS) it can also be used for liquid fuels production. Methanol, one of the reactants for biodiesel production, can be produced by synthesis gas with a $\mathrm{H}_{2} / \mathrm{CO}$ ratio of 2 .

Methane steam reforming (SR) is the primary way used by industry to produce syngas (Laosiripojana e Assabumrungrat, 2005; Hou e Hughes, 2001; Basini, 2005). The overall process is endothermic and catalytic (generally, nickel supported on alumina catalysts are used) and the reaction proceeds with an increase in the total number of molecules (Basini, 2005). SR is conducted at high temperatures, i.e., in the range from 850 to $900^{\circ} \mathrm{C}$ (Chang et al., 2010), low pressure, and high steam-to-methane ratio (S/M). These conditions greatly increase the manufacturing costs of syngas production (Chang et al., 2010; Akbari et al., 2011).

Another proposed technology is the autothermal reforming (ATR) of methane, which combines the PO and SR processes within the same reactor. According to Takeguchi et al. (2003), ATR is an adiabatic [i.e., thermally self-sustaining (Halabi, et al, 2008.; Chang et al., 2010; Hagh, 2004; Rabe et al., 2007)] reforming process composed of PO and SR reactions. 
However, the term ATR has recently been used to mean the combination PO and SR, irrespective of whether the process is conducted under adiabatic conditions or under non-zero exchanged heat conditions. ATR can be carried out over a wide range of the $\mathrm{H} / \mathrm{C}$ ratio in the syngas product. This is achieved by manipulating the relative inlet concentrations of steam and oxygen (Souza e Schmal, 2005; Santos et al., 2010; Liu et al., 2000; Liu et al., 2002).

So far the thermodynamic analysis of ATR reactions has been conducted by Gibbs free energy minimization (GFEm) (Vagia e Lemonidou, 2008; Chen et al., 2010; Li et al., 2008; Wang et al. . 2009. The GFEm method is used to find the thermodynamic equilibrium of a reactive multicomponent system, of given initial composition, and known pressure and temperature. However an ATR reaction does not evolve under constant temperature and pressure conditions in a continuous adiabatic reactor. In such a reactor, the known information for the outlet stream is the enthalpy rather than the temperature. Appendix $\mathrm{C}$ shows how the variables that should be kept constant are the system enthalpy and pressure, during the calculation, through a single straightforward optimization, of the equilibrium condition for a (strictly adiabatic) ATR reaction. At known enthalpy and pressure the proper variable to be optimized is the system entropy, which has to be maximized (Michelsen, 1999).

The aim of this work is to carry out thermodynamic analysis of autothermal reforming of methane for synthesis gas production employing entropy maximization method at known pressure and enthalpy, to determine the equilibrium composition and temperatures. Our calculations results attempt to illustrate the effects of the process variables such as pressure, temperature and the relative feed ratios (water/methane and oxygen/methane) to obtain the specific properties to useful synthesis gas to synthesis reactions.

\section{METHODOLOGY}

The chemical and phase equilibrium of an isobaric and isenthalpic closed (multicomponent) reaction system, with a given inlet composition, may be obtained by the total entropy maximization of the system with respect to $n_{i j}$ and T. The total entropy is given by:

$$
S^{t}=\sum_{i=1}^{N C} \sum_{j=1}^{N P} n_{i j} \cdot \bar{S}_{i j}\left(n_{i j}, T\right)
$$

where $S^{t}$ is the total entropy, $N C$ is the number of components in the system, $N P$ is the number of phases, $n_{i j}$ is the number of moles of component $i$ in phase $j, \bar{S}_{i j}$ is the partial molar entropy of component $i$ in phase $j$, and $T$ is the absolute temperature. 
The total entropy is to be maximized subject to the following restrictions:

-Non-negativity of numbers of moles:

$n_{i j} \geq 0, i=1, \ldots, N C ; j=1, \ldots, N P$

-Conservation of mass, given by the elemental mass balances:

$$
\sum_{i=1}^{N C} \sum_{j=1}^{N P} a_{m i} \cdot n_{i j}=\sum_{i=1}^{N C} a_{m i} \cdot n_{i}^{0}=b_{m}, \quad m=1, \ldots, N E
$$

where $a_{m i}$ is the number of atoms of type $m$ in a molecule of component $i, n_{i}^{0}$ is the inlet total number of moles of component $i, b_{m}$ is the total inlet number of moles of atoms of type $m$, and $N E$ is the number of types of atoms present in the system.

-Enthalpy conservation:

$$
\sum_{i=1}^{N C} \sum_{j=1}^{N P} n_{i j} \cdot \bar{H}_{i j}=\sum_{i=1}^{N C} n_{i}^{0} \cdot \bar{H}_{i}^{0}=H
$$

where $\bar{H}_{i j}$ is the partial molar enthalpy of component $i$ in phase $j, \bar{H}_{i}^{0}$ is the inlet partial molar enthalpy of component $i$, and $H$ is the total inlet enthalpy of the system.

The optimization also requires the satisfaction of the following constraint:

-Non-negativity of the absolute temperature:

$$
T \geq 0
$$

Once the reaction system is at high temperature, the formation of a liquid phase may be disregarded, and the gas phase may be assumed to behave as an ideal gas. In this work, the possible presence in the reactive system of the following components has been considered: methane, carbon monoxide, carbon dioxide, steam, hydrogen, oxygen, nitrogen, and solid carbon $[37,38,39]$. The solid phase has been regarded as composed only of pure graphite (a form of solid carbon).

The simultaneous chemical and phase equilibrium computation by the EMM is a non-linear programming (NLP) problem. The calculations have been performed using the software GAMS 21.6 (General Algebraic Modeling System), with the CONOPT2 solver option. CONOPT2 uses the Generalized Reduced Gradient approach. A Core i3 (4.00 GB, $2.40 \mathrm{GHz})$ computer has been used to perform all simulations. In all cases the computational time was less than $1 \mathrm{~s}$ for a single entropy maximization. 


\section{RESULTS AND DISCUSSIONS}

A thermodynamic analysis of methane autothermal reforming were performed using entropy maximization method to investigate the effects of pressure, inlet temperature, inlet steam-to-methane $(\mathrm{S} / \mathrm{M})$ ratio and inlet oxygen-to-methane $(\mathrm{O} / \mathrm{M})$ ratio on the syngas production for synthesis reactions. The ranges considered for the $\mathrm{O} / \mathrm{M}$ and the $\mathrm{S} / \mathrm{M}$ ratios varied from 0.0 to 0.5 and from 0.25 to 5 , respectively. The range for the inlet temperature was from 400 to $1000{ }^{\circ} \mathrm{C}$, and for the pressure from 1 to 50 bar. This window of conditions was defined in consideration of previous experimental and theoretical works on methane ATR (Halabi et al., 2008; Chang et al., 2010; Akbari et al., 2011; Dias e Assaf, 2004; Santos et al., 2010; Chen et al., 2010; Li et al., 2008; Reese et al., 2010; Simeone et al., 2008; Ayabe et al., 2003; Escritori et al., 2009; Souza et al., 2010; Hoang et al., 2006; Dantas et al., 2010), except for the $\mathrm{O} / \mathrm{M}$ ratio. A higher $\mathrm{O} / \mathrm{M}$ ratio, in fact, implies a higher equilibrium temperature. The maximum value for the $\mathrm{O} / \mathrm{M}$ ratio is limited by the maximum temperature of applicability of the equations used to calculate the heat capacity $\left(\mathrm{C}_{\mathrm{p}}\right)$ of the components of the reactive system. Thus, $\mathrm{O} / \mathrm{M}$ ratios greater than 0.5 resulted in equilibrium temperatures above such limit, which implies the lack of physical significance for the computed equilibrium.

An important parameter to evaluate the usage of synthesis gas is $\mathrm{H}_{2} / \mathrm{CO}$ ratio. Figure 1 shows the $\mathrm{H}_{2} / \mathrm{CO}$ ratio as a function of $\mathrm{O}_{2} / \mathrm{CH}_{4}$ and $\mathrm{S} / \mathrm{CH}_{4}$ ratios for different pressures and initial temperatures. As it can be observed, these parameter generally increase with the increase of the steam feed and increase with the decrease of oxygen feed. For the highest inlet temperature evaluated, in the region of low $\mathrm{O}_{2} / \mathrm{CH}_{4}$ ratio, there is a minimum point with relation of $\mathrm{S} / \mathrm{CH}_{4}$ ratio. Regarding the inlet temperature, the higher the inlet temperature is, the lower value of the $\mathrm{H}_{2} / \mathrm{CO}$ ratio, this can be seen by comparing the graphs of Figure 1. Regarding the pressure, generally the higher pressure is, the lowest value of $\mathrm{H}_{2} / \mathrm{CO}$ ratios.

As it can be seen in Fig. 1, the methane ATR is capable to providing a syngas with a wide range of $\mathrm{H}_{2} / \mathrm{CO}$ ratio values. However, in their final use in synthesis reactions, the synthesis gas must to present specific values of this parameter. In this sense, it were developed a iterative calculation routine able to explore in more detail the operating conditions where specific values of $\mathrm{H}_{2} / \mathrm{CO}$ ratio occur. An example is the synthesis of methanol which requires that $\mathrm{H}_{2} / \mathrm{CO}=2$. Therefore we determine the operating conditions under which, in equilibrium, is produced synthesis gas with $\mathrm{H}_{2} / \mathrm{CO}=2$. 


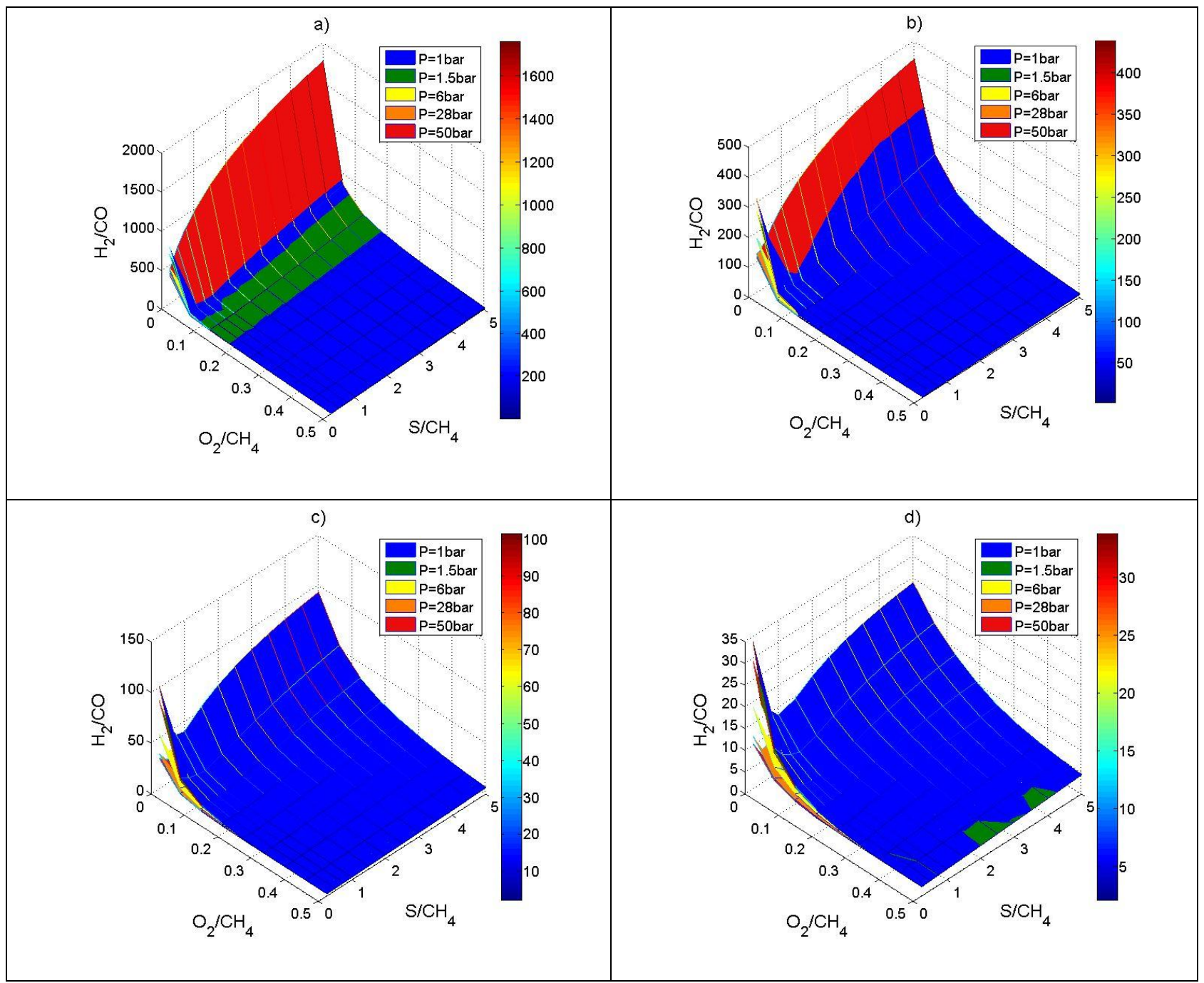

Figura $1-\mathrm{H}_{2} / \mathrm{CO}$ ratio methane as a function of the inlet $\mathrm{S} / \mathrm{M}$ and $\mathrm{O} / \mathrm{M}$ ratios, at several pressure and inlet temperature values: a) $400{ }^{\circ} \mathrm{C}$, b) $500{ }^{\circ} \mathrm{C}$, c) $700{ }^{\circ} \mathrm{C}$ and d) $1000{ }^{\circ} \mathrm{C}$.

Figure 2 shows the conditions of $\mathrm{O}_{2} / \mathrm{CH}_{4}$ and $\mathrm{S} / \mathrm{CH}_{4}$ for different pressures and initial temperatures where $\mathrm{H}_{2} / \mathrm{CO}=2$. In this Figure it can be seen that the increasing of pressure rise the region where $\mathrm{H}_{2} / \mathrm{CO}$ is equal 2. The values of $\mathrm{O}_{2} / \mathrm{CH}_{4}$ ratio are the largest within the range considered, and the $\mathrm{S} / \mathrm{CH}_{4}$ ratio are very low. 

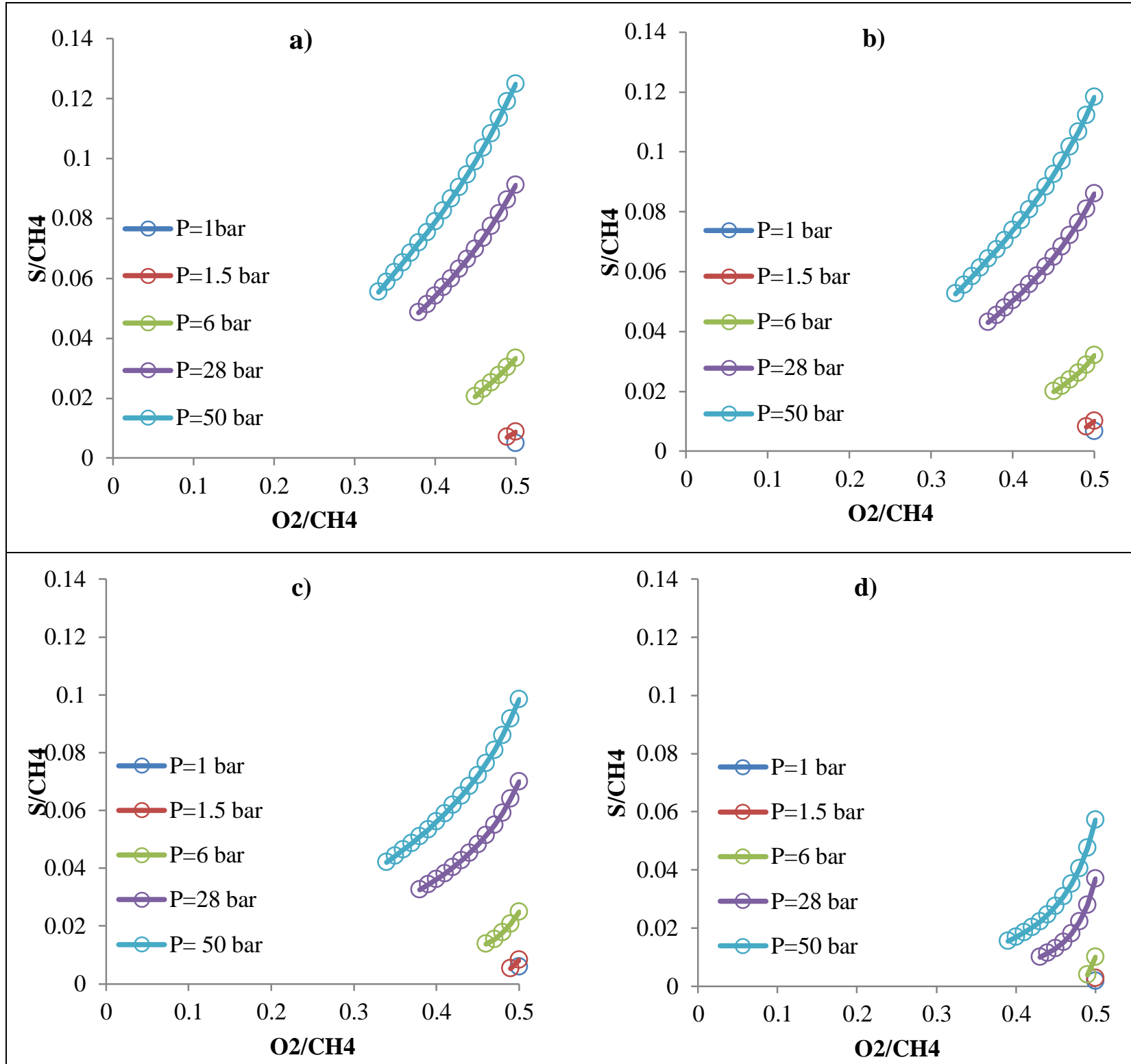

Figure 2 - Conditions for $\mathrm{H}_{2} / \mathrm{CO}$ equals 2 at several pressures and inlet temperature values: a) 400 ${ }^{\circ} \mathrm{C}$, b) $500{ }^{\circ} \mathrm{C}$, c) $700{ }^{\circ} \mathrm{C}$ and d) $1000^{\circ} \mathrm{C}$. Symbols: $\bigcirc \mathrm{P}=1 \mathrm{bar} ; ~ \mathrm{P}=1,5 \mathrm{bar} ; ~ \mathrm{P}=6 \mathrm{bar}$; $\neg \mathrm{P}=28 \mathrm{bar} ; \multimap \mathrm{P}=50 \mathrm{bar}$.

The sum of moles of $\mathrm{H}_{2}$ and $\mathrm{CO}$ show the relative quantity of synthesis gas produced. Figure 3 a) shows the $\left(\mathrm{H}_{2}+\mathrm{CO}\right) / \mathrm{CH}_{4}$ as a function of temperature for $\mathrm{O}_{2} / \mathrm{CH}_{4}=0.5$ (in these conditions $\mathrm{H}_{2}+\mathrm{CO}$ reaches the maximum values) in different pressures. As it can be seen in this Figure, the syngas production increase with the increasing of inlet temperature and decrease with the increasing of pressure. Figure $3 \mathrm{~b}$ ) shows the equilibrium temperature at the same conditions. The equilibrium 
temperature is always higher than inlet temperature, and increase with pressure.
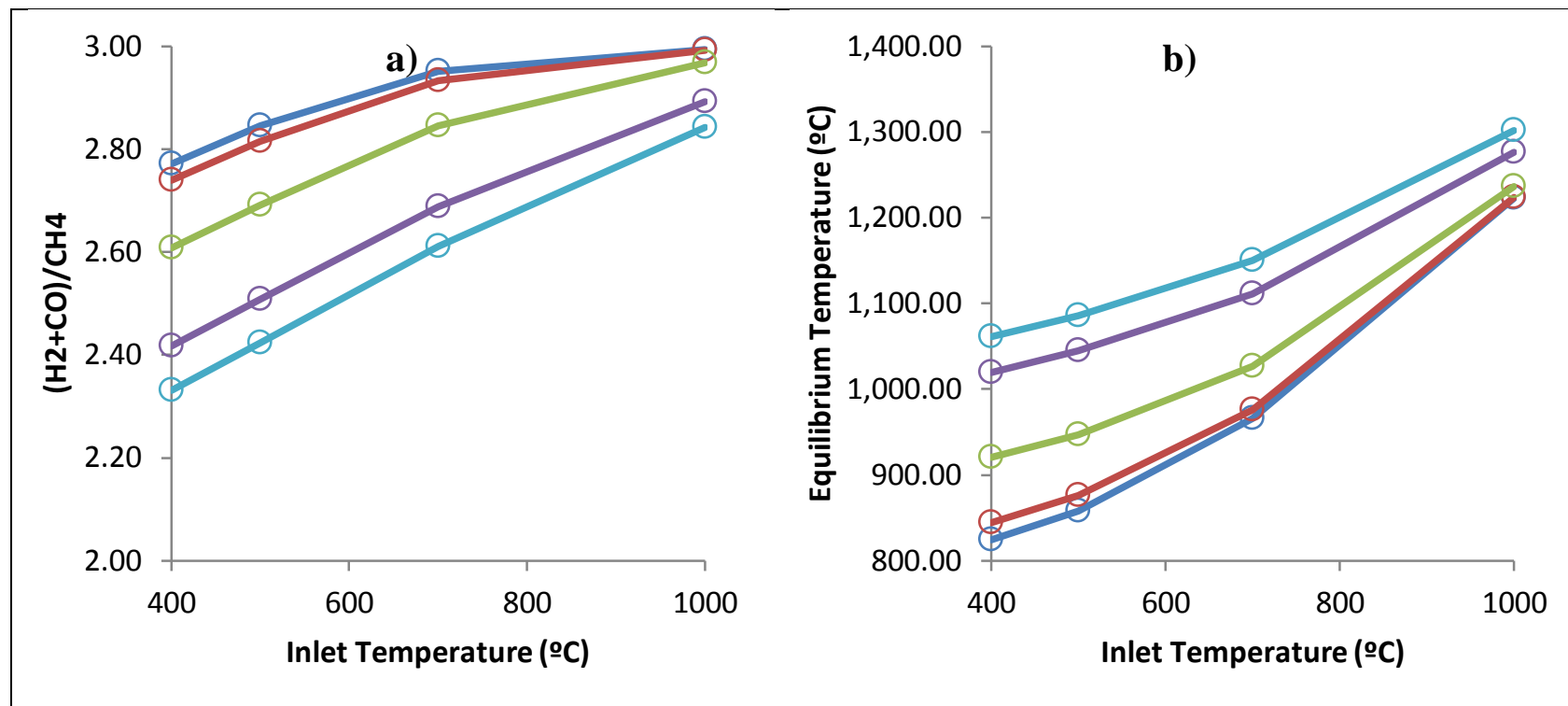

Figure $3-\mathrm{a})\left(\mathrm{H}_{2}+\mathrm{CO}\right) / \mathrm{CH}_{4}$ and b) equilibrium temperature as a function of inlet temperature at $\mathrm{O}_{2} / \mathrm{CH}_{4}=0.5$ and at several pressures. Symbols: $\mathrm{P}=1$ bar; $-\mathrm{P}=1,5 \mathrm{~b}$ ar; $-\mathrm{P}=6 \mathrm{bar}$; P=28bar; $\mathrm{P}=50 \mathrm{bar}$.

\section{CONCLUSIONS}

A thermodynamic analysis of the ATR of methane, carried out through the EMM, has been performed in this work to find conditions that produces syngas for synthesis reactions over wide ranges of composition, temperature and pressure. The computations considered the chemical and phase equilibrium simultaneously (ideal gas phase, at equilibrium with a pure carbon solid phase). The EMM can directly find the equilibrium corresponding to the thermoneutral condition. It does it through a single optimization which simultaneously provides complete information, in particular, the equilibrium composition and temperature.

\section{REFERENCES}

Akbari, M. H.; Ardakani, A. H. S.; Tadbir, M. A. A microreactor modeling, analysis and optimization for methane autothermal reforming in fuel cell applications. Chem. Eng. J., v. 166, p. 1116-25, 2011. 
Ayabe, S. ; Omoto, H.; Utaka, T.; Kikuchi, R.; Sasaki, K.; Teraoka, Y. et al. Catalytic autothermal reforming of methane and propane over supported metal catalysts. Appl. Catal. A: Gen., v. 241, p. 261-9, 2003.

Basini, L. Issues in $\mathrm{H}_{2}$ and synthesis gas technologies for refinery, GTL and small and distributed industrial needs. Catal. Today, v. 106, p. 34-40, 2005.

Chang, H. F.; Pai, W. J.; Chen, Y. J.; Lin, W. H. Autothermal reforming of methane for producing high-purity hydrogen in a $\mathrm{Pd} / \mathrm{Ag}$ membrane reactor. Int. J. Hydrogen Energ., v. 35, p. 12986-92, 2010.

Chen, W. H.; Lin, M. R.; Lu, J. J.; Chao, Y.; Leu, T. S. Thermodynamic analysis of hydrogen production from methane via autothermal reforming and partial oxidation followed by water gas shift reaction. Int. J. Hydrogen Energ., v. 35, p. 11787-97, 2010.

Dantas, S. C.; Escritori, J. C.; Soares, R. R.; Hori, C. E. Effect of different promoters on $\mathrm{Ni} / \mathrm{CeZrO}_{2}$ catalyst for autothermal reforming and partial oxidation of methane. Chem. Eng. J., v. 156, p. 380-7, 2010.

Dias, J. A. C., Assaf, J. M. Autothermal reforming of methane over $\mathrm{Ni} / \gamma-\mathrm{Al}_{2} \mathrm{O}_{3}$ catalysts: the enhancement effect of small quantities of noble metals. J. Power Sources, v. 130, p. 10610, 2004.

Escritori, J. C.; Dantas, S. C.; Soares, R. R.; Hori, C. E. Methane autothermal reforming nickelceria-zirconia based catalysts. Catal. Commun., v. 10, p. 1090-4, 2009.

Gao, J.; Guo, J.; Liang, D.; Hou, Z.; Fei, J.; Zheng, X. Production of syngas via autothermal reforming of methane in a fluidized-bed reactor over the combined $\mathrm{CeO}_{2}-\mathrm{ZrO}_{2} / \mathrm{SiO}_{2}$ supported Ni catalysts. Int. J. Hydrogen Energ., v. 33, p. 5493-500, 2008.

Hagh, B. F. Stoichiometric analysis of autothermal fuel processing. J. Power Sources, v. 130, p. 85-94, 2004.

Halabi, M. H.; Croon, M. H. J. M.; van der Schaaf, J. Modeling and analysis of autothermal reforming of methane to hydrogen in a fixed bed reformer. Chem. Eng. J., v. 137, p. 56878, 2008.

Hoang, D. L.; Chan, S. H.; Ding, O. L. Hydrogen production for fuel cells by autothermal reforming of methane over sulfide nickel catalyst on a gamma alumina support. J. Power Sources, v. 159, p. 1248-57, 2006.

Hou, K.; Hughes, R. The kinetics of methane steam reforming over a $\mathrm{Ni} / \alpha-\mathrm{Al}_{2} \mathrm{O}$ catalyst. Chem. Eng. J., v. 82, p. 311-28, 2001.

Laosiripojana, N.; Assabumrungrat, S. Methane steam reforming over Ni/Ce-ZrO2 catalyst: Influences of $\mathrm{Ce}-\mathrm{ZrO} 2$ support on reactivity, resistance toward carbon formation, and intrinsic reaction kinetics. Appl. Catal. A: Gen., v. 209, p. 200-11, 2005.

Li, Y.; Wang, Y.; Zhang, X.; Mi, Z. Thermodynamic analysis of autothermal steam and $\mathrm{CO}_{2}$ reforming of methane. Int. J. Hydrogen Energ., v. 33, p. 2507-14, 2008. 
Liu, K.; Song. C.; Subramani, V. Hydrogen and Syngas Production and Purification Technologies. New Jersey: John Wiley \& Sons; 2010.

Liu, S.; Xiong, G.; Dong, H.; Yang, W. Effect of carbon dioxide on the reaction performance of partial oxidation of methane over a LiLaNiO $/ \gamma-\mathrm{Al}_{2} \mathrm{O}_{3}$ catalyst. Appl. Catal. A: Gen., v. 202, p. 141-6, 2000.

Liu, Z. W.; Jun, K. W.; Roh, H. S.; Park, S. E. Hydrogen production for fuel cells through methane reforming at low temperatures. J. Power Sources, v. 111, p. 283-7, 2002.

Michelsen, M. L. State function based flash specifications. Fluid Phase Equilibria, v. 160, p. 617-26, 1999.

Rabe, S.; Truong, T. B.; Vogel, F. Catalytic autothermal reforming of methane: Performance of a kW scale reformer using pure oxygen as oxidant. Appl. Catal. A: Gen., v. 318, p. 54-62, 2007.

Reese, M. A.; Turn, S. Q.; Cui, H. Kinetic modeling of high pressure autothermal reforming. $J$. Power Sources, v. 195, p. 553-8, 2010.

Santos, D. C. R. M.; Madeira, L.; Passos, F. B. The effect of the addition of $\mathrm{Y}_{2} \mathrm{O}_{3}$ to $\mathrm{Ni} / \alpha-\mathrm{Al}_{2} \mathrm{O}_{3}$ catalysts on the autothermal reforming of methane. Catal. Today, v. 149, p. 401-6, 2010.

Simeone, M.; Salemme, L.; Allouis, C. Reactor temperature profile during autothermal methane reforming on Rh/Al2O3 catalyst by IR imaging. Int. J. Hydrogen Energ., v. 33, p. 4798808, 2008.

Souza, A. E. A. M.; Maciel, L. J. L.; Filho, M. L.; Abreu, C. A. M. Catalytic activity evaluation for hydrogen production via autothermal reforming of methane. Catal. Today, v. 149, p. 413-7, 2010.

Souza, M. M. V. M.; Schmal, M. Autothermal reforming of methane over $\mathrm{Pt} / \mathrm{ZrO}_{2} / \mathrm{Al}_{2} \mathrm{O}_{3}$ catalysts. Appl. Catal. A: Gen., v. 281, p. 19-24, 2005.

Takeguchi, T.; Furukawa, S. N.; Inoue, M.; Koichi, E. Autothermal reforming of methane over $\mathrm{Ni}$ catalyst supported over $\mathrm{CaO}-\mathrm{CeO}_{2}-\mathrm{ZrO}_{2}$ solid solution. Appl. Catal. A: Gen., v. 240, p. 223-33, 2003.

Vagia, E. C.; Lemonidou, A. A. Thermodynamic analysis of hydrogen production via autothermal steam reforming of selected components of aqueous bio-oil fraction. Int. J. Hydrogen Energ., v. 33, p. 2489-500, 2008.

Wang, H.; Wang, X.; Li, M.; Li, S.; Wang, S.; Ma, X. Thermodynamic analysis of hydrogen production from glycerol autothermal reforming. Int. J. Hydrogen Energ., v. 34, p. 568390, 2009. 